\title{
GAUGING THE REACTIONS TO REMOTE WORKING AT IBM JAPAN DURING THE PERIOD OF COVID-19
}

\author{
Kurtz LAW \\ Bucharest University of Economic Studies, Romania \\ kurtz.law@man.ase.ro \\ Toru TAKAHASHI \\ Bucharest University of Economic Studies, Romania \\ t-takahashi@globis.ac.jp \\ Cristian VLAD \\ Bucharest University of Economic Studies, Romania \\ cristian@japancreativeenterprise.jp \\ Kyoko KOKUSHO \\ IBM Japan, Tokyo, Japan \\ Saddam IQBAL \\ Babes-Bolyai University,Cluj Napoca, Romania \\ saddam.iqbal@econ.ubbcluj.ro
}

\begin{abstract}
The Japanese corporate mindset often tends towards a more conservative stance compared to that of the West. However, Japan has the most companies with a continuous operation history of over 200 years, having survived many turbulent times including pandemics and war. How then, might companies of today learn from Japanese success cases? Sustainability and longevity are commonly based on the successes born from past corporate history, but with the COVID-19 pandemic, severe internal effects, and economic impacts suggests a need for an agility that most Japanese companies are not familiar with. This research utilizes modified unstructured focus groups to investigate IBM Japan's employees' perceptions of remote working at the during the COVID-19 pandemic.
\end{abstract}

Keywords: COVID-19, Corporate Culture, Remote Work, IBM, Japan

DOI: https://doi.org/10.24818/beman/2021.S.I.2-13 


\section{INTRODUCTION}

This article focuses on the data gathered from a company-wide event where employees had an opportunity to discuss the effects and impacts of remote working during the early-middle stages of the COVID-19 pandemic.

As of June 5th 2020, 307,462 people had been tested for the COVID-19 disease in Japan and of this number $5.5 \%$ of test cases had been confirmed. In addition, $5.3 \%$ of infected people had died of this disease in Japan (Ministry of Health, Labour and Welfare, 2020a; Statista, 2020a). The 2018 census reported a total population of 126.44 million (Statistics Bureau of Japan, 2019), and Iwasaki \& Grubaugh (2020) stated that despite Japan's population density being 2.4 times that of New York city, occurrence of the disease had been very low. Indeed, just in terms of perspective, the total population of New York city as of 2019 amounted to around 8.34 million (New York City government, 2019) and yet had contracted over 204,377 cases of which 10.4\% of COVID-19 infected people had died (New York Times, 2020; Statista, 2020b). It has been suggested that people who are most at risk of COVID-19 are the elderly, and those with pre-existing conditions, such as obesity and organ-related illnesses (Peron and Nakaya, 2020; Takehara, 2020). It might therefore be suggested that people in the US have a larger proportion of population who are affected by COVID-19 risk-related conditions. The Japanese health system may also be another factor which had led to a significant lessening of the impact of the disease at that time. Japan aims towards disease prevention and control than cure and treatment. This includes fully remunerated, mandatory annual medical health-checks for all employees (Sakamoto, et al. 2018). Consequently, it is likely that Japanese employees are more aware of their health condition and are consistently pressured by medical professionals to conform to what is perceived as a good standard of health.

\section{LITERATURE REVIEW}

As of June 2021, Japan's vaccination rate against the COVID-19 pandemic accounted for around $6.2 \%$ of the total population, approximately 15.6 million doses (Reuters, 2021). This is significantly lower than that of other countries for example, the UK representing $58.1 \%$, Italy $39 \%$, or even India at $12.1 \%$ (Our World in Data, 2021). Nonetheless, on the whole, the vaccination rate in Japan exceeds that of the OECD average, and the Japanese population have the tendency to use precautionary and hygienic measures such as widespread use of medical face masks and regular handwashing (OECD, 2019). According to Burgess and Horii (2012), these practices stem from the 1919 Spanish Flu pandemic, where the Central Sanitary Bureau recommended the wearing of masks alongside vaccinations and gargling. Surveys carried out in 2009 determined that $22.8 \%$ of Japanese wore medical face masks on a daily basis for the prevention of influenza (Interwired, 2009). And, of the $41.2 \%$ of Japanese reported being affected by hay- 
fever or pollen allergies, over $48 \%$ were reported to wear masks as a preventative measure (Statista, 2020c; Morishima, et al. 2011). It is important to note, that such cultural acceptance of medical face masks existed pre-COVID-19, and that no hesitancy would have prevented people from applying them immediately and correctly.

February and March are commonly anticipated for the peak hay-fever season in Japan which coincidentally corresponded at the same time as the outbreak of COVID-19. This implies that a significant proportion of the Japanese population would have been wearing face masks at the onset of the outbreak for this disease. On the other hand, the US has had many cases where the wearing of medical face masks had been culturally rejected (Prasad, 2020; Lithwick, 2020) and it has been suggested that mandatory face masks represent an attack on individual freedom (Aratani, 2020).

Many Western countries have responded to the proliferation of the disease in relatively the same way albeit with different levels of social acceptance and timing (World Health Organization, 2020; European Centre for Disease Prevention and Control, 2020). In the U.K. and EU, governments imposed legal regulations to enforce social distancing, wearing of face coverings and suspension of business activities and have backed these methods up with penalties. However, although the Japanese government offered strong recommendations, obedience was not mandatory (Prime Minister of Japan and His Cabinet, 2020). IBM Japan, which is the subject of this research however, ordered its employees to begin working from home in response to growing concerns regarding the spread of Coronavirus. IBM Japan is a Japanese commercial services company which was founded in the 1930s. Today, they have 21,568 employees including subsidiaries in Japan and a capitalization of over 105 billion yen. The majority of their facilities are located in the area of Tokyo, and the majority of its employees that took part in our study lived within a one-hour commute. Communication is valued highly in IBM's corporate culture, and managers began to report that employees were discussing the issue of remote working nationally across teams. In response to this, the president of the company requested that a centralized discussion system be setup to enable the employees to provide feedback and advice on remote working during the COVID-19 circumstance.

\section{RESEARCH OBJECTIVES}

This research examines IBM data for the online digital event, "IBM JAM" which occurred in May 2020 on the topic of remote working in Japan during the COVID-19 circumstance. The main purpose of the event was as an internal initiative aimed at gauging employee reaction to mandatory home-based work. This article seeks to represent the findings of this research event and to highlight the main issues raised by the participants. It also seeks to clarify Japanese cultural context for the responses which may be 
unfamiliar to people from the West. Examples of which include tatami rooms and low tables, sitting on the floor and the available size of living space. These elements of Japanese culture will be discussed in context in the data analysis and findings section.

\section{RESEARCH METHODOLOGY}

In May 2020, the Strategy and Planning division organized and launched a ten-day online event inviting all 21,568 employees to participate. They utilized an established and well-used internal social networking site (SNS). This SNS was being used on a day-to-day basis by employees and management to communicate on a variety of topics. During the event, it was known that management would have access to employee comments, identification details and that data analysis and oversight was possible. This may have had an impact on the number of contributions, and employee openness when participating (Sim \& Waterfield, 2019; Detert \& Burris, 2016). In terms of ethical considerations, normally for focus groups it is necessary to get participants' informed consent. However, in this case management explicitly informed employees that participation was fully voluntary. Participants could opt-out of topics which they considered to be too sensitive to them. The SNS mechanism enabled users to perform modified unstructured focus groups to discuss four main topics. As shown in Figure 1.

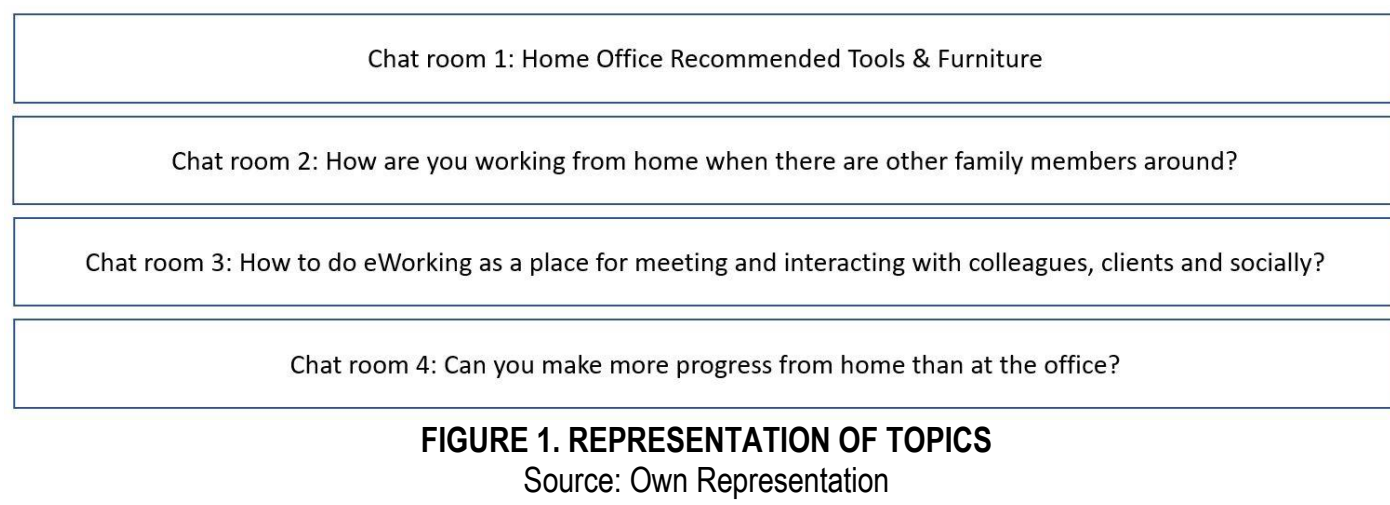

Our research method did not fit the conventional focus group model as 7,134 employees joined the chat rooms to view content, and over 970 employees commented by text in the chat rooms available as demonstrated in Figure 2. 
Chat room 1:

Discussion about physical discomfort

在宅勤務が続いています。そしてコロナ収束、薬やワクチンができるまで、以前と同様に会社に行って仕事をする、と言う生活が完 全に戻ることは難しいので、できるだけ環境を整えていらっしゃると思います。私もこの機会に仕事用に椅子を買おうかと思ってい

P1 るのですが、通販では選べません。どなたか、これはおすすめ!と言う（お手頃の）椅子がありましたら教えてください。 I've been working from home due to the COVID-19 pandemic. It is difficult to work as usual ... I'm thinking about buying an office chair but I can't decide which one. Can someone recommend one?

オカムラの『バロン』という椅子を恐らくもう10年? ばかり自宅で使っていますが机でPC作業する分には文句なくおすすめです。 スカスカに通気性のあるメッシュ地で暑くて蒸れるような不快感とは無緑です。ただし全くもってお手頃ではなく、覚悟の要る投

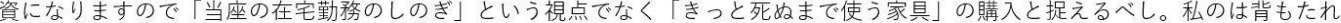
が頭の後ろまで支えられる高さのある造りのモデルです。据え置き型外付けモニタを視線が水平になる程度の高さにして常用する環

P2 境にこの頭の後ろを支えてくれる椅子があると、难椎にはまるで負担がかからないです。

I've been using Okamura's Baron chair for 10 years. I definitely like it for working when using a PC at a desk. It has a breathable mesh fabric which is free from the discomfort of being hot and stuffy. However, it is not very affordable and it is an investment that requires consideration. It should be regarded as a purchase of furniture that will be used "until death" rather than from the viewpoint of working from home "for the time being". My chair model is tall enough to support the back of my head ... so that my spine is not burdened at all.

バロンはいいって聞いたことがありまするそういえば まだ若手だった頃に岡村製作所の方とセミナーでごー緒した際「「ー人暮ら

P3 しをしてるうちに、いいオフィスチェアを自宅用に買っておくといいよ」

I've heard that the Baron chair is good. By the way, when I was young, I went to a seminar and was told, "While living alone, you should buy a good office chair for your home."

\section{FIGURE 2. DEMONSTRATION OF DISCUSSION WITHIN CHAT ROOMS}

\section{Source: Own Representation}

While it is suggested that large numbers of participants in focus groups becomes unmanageable, familiarity with this form of communication prevented too many tangents from being formed, or alternatively tangents spun off to become side topics as shown in figure 3. In this example, the original intention was for the company to discover how employees felt about the efficacy of using home furniture to perform work tasks, and the availability of home equipment and software to fulfil work needs. However, a discussion emerged about whether the company would provide a budget for expensive items such as office chairs, displays and audio equipment. Additionally, a further discussion emerged regarding what would happen to the office equipment once the COVID-19 pandemic ended, and the employees returned to the office. These discussions were considered valuable, but not directly conducive to supporting the main topic, as a result the moderator requested administrators to spin off these tangent conversations into their own respective chat rooms as demonstrated in Figure 3. 


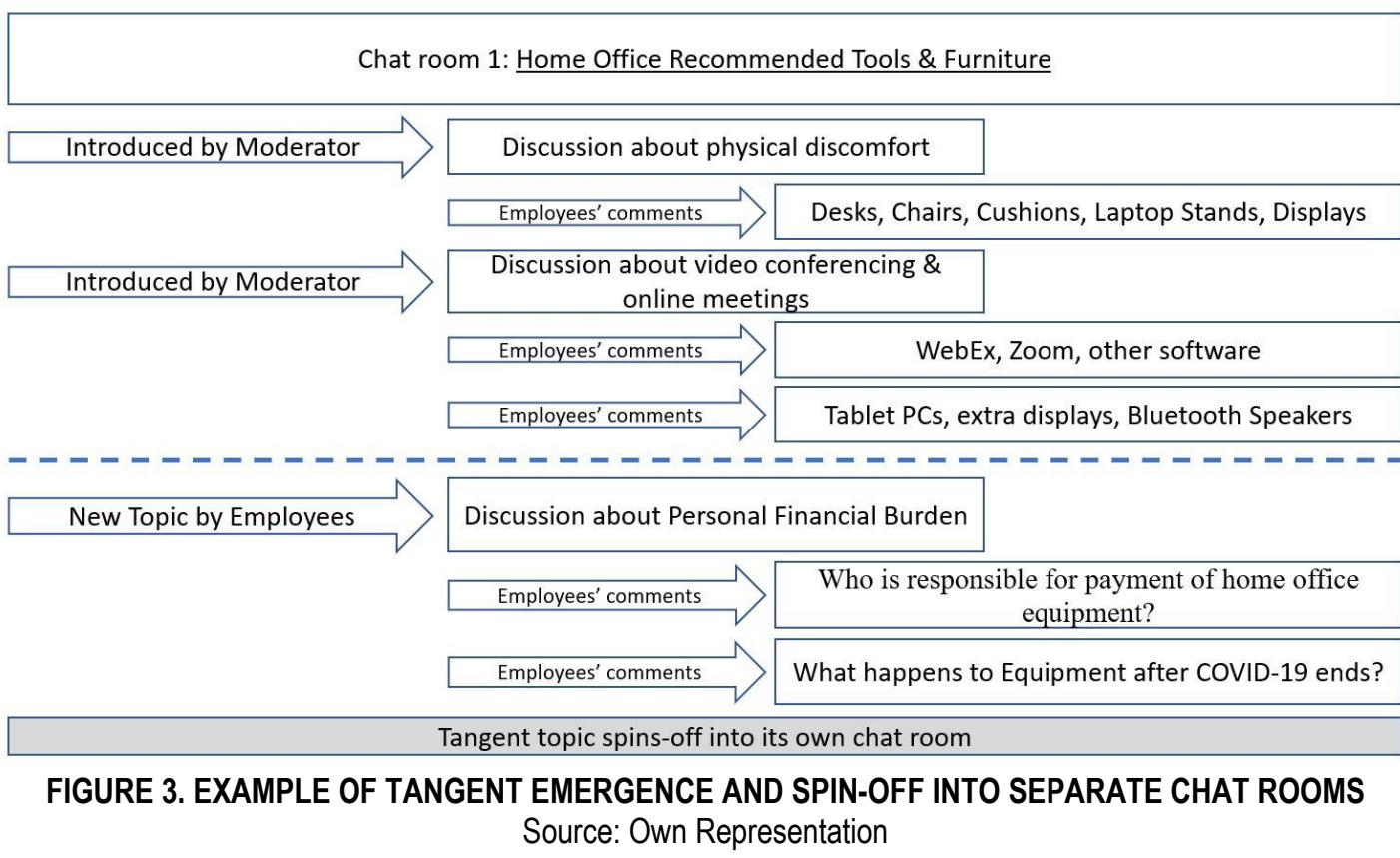

In this study, the data analysis was carried out in the following process: participants' responses were collected in the native Japanese language and translated into English and through the use of the qualitative research tool NVIVO, the researchers transcribed, read and comprehended the data. Meaningful words, phrases and concepts were highlighted and coded and similar codes were grouped into categories and finally grouped into themes. Finally, thematic descriptions were developed to explain the participants' experiences relating to the research topic. Themes had several categories such as shown in Figure 4.

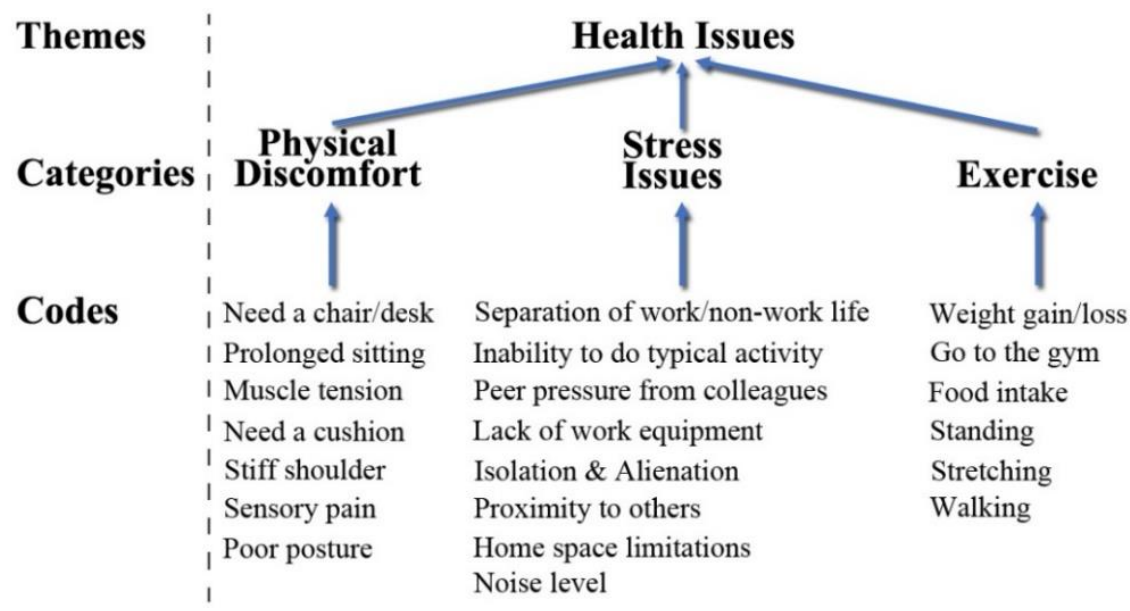

FIGURE 4. ILLUSTRATION OF THE CODES, CATEGORIES AND THEMES

Source: Own Representation

While several other interesting themes were derived in addition to Health Issues, including home office expenditure and worker productivity issues, for the scope of this article, we will not focus on them. 


\section{FINDINGS}

Remote-work style suggests privacy, a sense of personal safety and the utilization of the home office with the freedom to purchase personal technology or furniture to heighten one's own comfort beyond that which the office might be willing to pay for. For example, the use of a stereo system at home, or other loud speakers may enhance the personal worker's experience but be incompatible with office space (Calisi \& Stout, 2015). In Japan, a designated home office pre-COVID19 was rare. According to the Statistics Bureau of Japan (2019) 19\% of enterprises had introduced telework, of which working from home represented $37.6 \%$. This has in part been due to the work-culture stemming from the desire to belong to the collective (Pathmaranjan, 2003) and a physical lack of home space. Therefore, from the onset of the initial directive to work from home, the majority of Japanese employees did not have a home office or an abundance of home office equipment.

$23 \%$ of our participants, on the issue of physical discomfort made specific reference to having a need for an office chair and $17 \%$ stated that they needed something that gave adequate back support. Consequently, many participants suggested buying an office chair or gaming chair with back support and reclining function. One participant said that he was watching celebrities on YouTube for advice about types of gaming chair to buy. In addition, $9 \%$ of respondents recommended posture chairs and different types of cushions to prevent discomfort. For example, the "house chair is not ergonomically designed for office work" was stated and on another common theme, "I don't have a desk or chair for work, so I sit at the dining room table or on my bed. I'm worried about getting backpain." Some participants bought types of desks which alleviated physical pain while working. Many bought seat cushions to be used on their existing chairs with good effect.

Participants stated that they were working from Western-style dining tables, or from Japanese low tables such as a kotatsu (demonstrated in Figure 5 ) and $5 \%$ of workers reported that their space was severely lacking, such that they felt that they had to work while sitting on their beds or floor. One participant in particular said that she "was dreading that sitting on the floor was going to hurt my back" and another stated, "I use four stacks of yoga mats when working from the floor". Whereas in the West it is relatively irregular to sit on the floor, culturally Japanese mindset is different. Japanese apartments and houses often have a traditional tatami room where the floor consists of rectangular mats made from dried grass. Regular tables and chairs which have sharp corners on the bases of the narrow legs are not suitable for this relatively fragile material. Therefore, sitting or kneeling on the floor is common. Participants stated that sitting on the floor while working has a tendency to contribute to back pain, muscle tension, stiff shoulders and poor posture. 


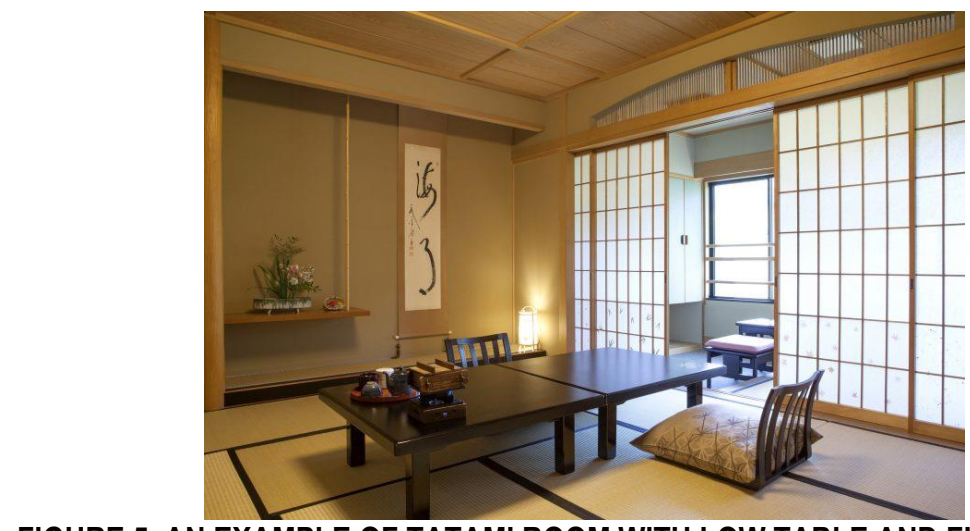

FIGURE 5. AN EXAMPLE OF TATAMI ROOM WITH LOW TABLE AND FLOOR CHAIR. Sourced from: Lambe (2019).

Working from home required employees to use media equipment such as earphones and headphone devices. One participant explains "earphones are particularly useful for hearing clearly during online meetings." However, another participant stated "using earphones for extended periods of time gives me a headache so I use a speakerphone instead." One participant tried multiple earphones and headphones to drown out noises from renovation work outside but they gave him ear and head pain. Suggestions were given regarding using soundproofing ear muffs instead or using earbuds and recommendations were made for using products that utilised mesh-type and breathable fabrics.

Eye strain, eye-aches and dry eyes were also physical discomfort that employees experienced from working at home. These were often caused by looking at the computer screens for long periods of time. One participant recommended using a pair of gaming eye-wear when looking at the computer screen, saying "since I started using these (gaming eye-wear), my eye fatigue has greatly decreased". Other participants also supported the use of gaming eye-wear.

On the issue of stress, Panigrahi (2018) defines it as a deviation from the normal functioning of the body and mind and indicates that in limited amounts can be beneficial to employees. The International Labour Organization (2016) however, examined stress from the negative aspect caused by individuals' inabilities to cope with their perceptions of work demands. Additionally, the International Labour Organization (1986) identified areas of work impacting health factors such as burnout, depression and physiological issues. Despite long standing awareness of these issues, they are still prevalent in work environments today. In particular, the key features of burnout were described as an interconnection between exhaustion and withdrawal leading to stress exceeding a person's level of tolerance.

Traditional concepts of work-related stress disorders in Japan have been reported on topics such as long working hours (Kikuchi, et al. 2020), train commuting, which has also been described as "tsukin jigoku" meaning commuting hell (Shimomitsu \& Haratani, 2000) and demonstrated in Figure 6, job insecurity 
(Inoue, et al. 2018), lack of control over work schedules and lack of regular days off. Perhaps unsurprisingly $75 \%$ of all comments from our data relating to the theme on health were stress related. $29 \%$ of participants commented that taking rush hour trains had a high impact on their mental health. Additionally, door to door commutes of between one and two hours were common. With train congestion rates exceeding that of $200 \%$ during rush hour (Yamauchi, et al. 2017) it is not such a leap to empathize with the conditions surrounding train commuting which contributes to a persistent growing level of stress. It is therefore important to note that remote work reduced the number of IBM Japan employees needing to take trains in the morning, for example participants stated their distaste for train commuting, "I can't imagine spending an hour or so on a crowded train to get to work like I used to." and "I'm fed up with commuting on a packed train." Additionally, it was stated, "In the past, l'd wake up, get dressed, catch the train and by the time I got to the office by 9am, l'd be exhausted." Other participants mentioned the benefits of remote working such as, "When I am sick, I can evaluate my condition as soon as I get up, I don't have to take a half day off for sickness." And, "the benefits of eliminating the commute are so great that I'm able to work remotely and efficiently." These suggest that employees' mental health has likely been improved by remote work.

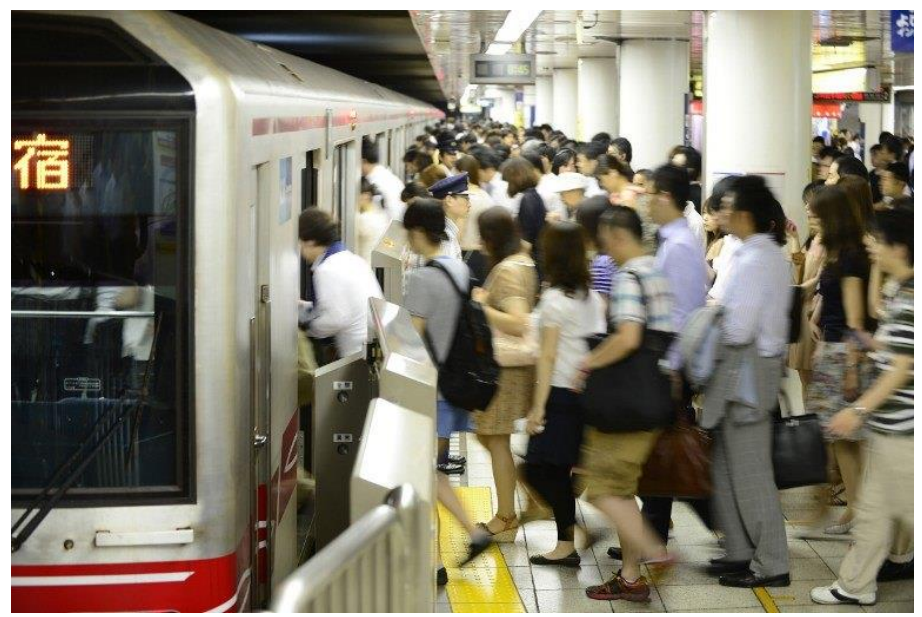

FIGURE 6. TYPICAL MORNING RUSH HOUR CROWD AT IKEBUKURO STATION IN TOKYO Sourced from: Borneo Post Online (2019)

An interesting development therefore has been introduced by the necessity of working from home, and the potential for more remote working in the future. While home ownership in Japan is around $61.7 \%$ (Kobayashi, 2015) and according to the 2018 Housing and Land Survey, the average area per dwelling in Tokyo and Kanto region is 58.94 and 70.85 square meters respectively (Statistics Bureau of Japan, 2018). In Tokyo, dwellings have an average of 2.83 rooms in addition to kitchen, bathroom and toilet, and Kanto as a whole 3.19 rooms. Furthermore, dwellings which have tatami rooms in Tokyo and the Kanto 
region are $22.52 \%$ and $26.93 \%$ respectively. In comparison, The United States Census Bureau (2021) indicates a homeownership rate of $65.8 \%$ and Grist (2010) identified an average dwelling size of 256.7 square meters across the US for new single-family houses. For context purposes it is important to note that around $70 \%$ of never married men and women aged in their 20 s and 30 s still live with their parents which is a socially accepted norm (Yu \& Kuo, 2019).

According to our data, other psychological issues in Japan have emerged from the introduction of remote working such as, family stress, lack of space, privacy among family members working in competing companies and in some cases isolation. Lack of space at home and interruption of work caused by family responsibilities such as taking care of children during school lockdowns was a common theme from our participants.

One participant stated, "For me, I get annoyed by household interruptions. For example, when I'm trying to gather my thoughts on a complex case." Another participant mentioned that "when we (working family members) have a web conferencing at the same time, one of us must use the bedroom, sitting on the bed as a chair," another stated, "where possible, the kids must go outside, and not come back before the meeting has ended." Other similar issues include, "my son is a college student but now he's home with my wife and I, and his classes are online." And, "we barely have enough space for us to work in. Not only do we have our family things, but now we have to keep our work things at home too." Space related stress also included the issue of work privacy. Participants reported the difficulty in ensuring company confidentiality. For example, one participant stated, "My wife's online meetings are basic chat, but I use WebEx which has audio. If the meeting is exciting, we can become quite loud. We must be careful not to see each other's screens." Another participant stated, "I choose to work from inside the car. It is not ideal but it is warm and I can protect my company information from my husband who works in the same industry."

Participants commented on the difficulty to work without face-to-face connections. Isolation is uncommon in Japanese companies, as they emphasize strong teamwork. Drinking parties known as nomikai are an integral part of Japanese business culture. Where people in the West might have lunch or go to the pub on Friday night with colleagues, and work friends, the Japanese have low-key, primarily team-based, social events late at night before going home (McDonald \& Sylvester, 2014; Shteynbok, 2013).

Negative comments were given for reduced work efficiency and direction such as, "the disadvantages of remote work are that I can't see people whenever I want. I don't get the live sensation of interacting with people." And, "when you're stuck, it's hard to know where to find help, or what to do next." Additionally, workers felt that they could not achieve the same relationship with clients without the ability to meet in person. "We've tried online dining, but it's difficult to build the same kind of rapport as meeting face-to- 
face." Also, "The disadvantages (of remote working) are that it's hard to make connections with colleagues who live alone and can feel lonely."

At IBM Japan, a channel named "Watercooler" was set up on Google Team Slack for chit-chat and congratulatory messages such as for birthdays and "we're having a baby." While technology is playing a part in remaining connected, participants stated, "I have found it stressful being based at home because the only way to communicate with people is through text or on a screen" and "there's less chitchat. I only have business conversations."

On the category of exercise, it has been suggested that under normal circumstances the Japanese in urban areas such as Tokyo, walk more on average than in the West. They use public transportation such as trains, and buses as their primary mode of commuting to work, or daily travel. Choice areas to live, are residences closer to their office or to train stations despite increased noise levels (Calimente, 2009). According to the Statistics Bureau (2019), the total volume of domestic passenger transport in 2017 was 31.25 billion passengers carried, an increase of $1.3 \%$ from 2016. Specifically, railways reported 24.97 billion passengers, and for motor vehicles 6.08 billion passengers carried. From our study, participants stated, "When I was working from the office, I often walked to and from the train station. Visiting clients meant that I would spend a lot of time standing or walking" and, "the cons of e-Work are that my daily walking exercise has dropped drastically." Additionally, "I used to get a lot of daily exercise when commuting between home, the office and my customers. But now I can't do that. I'm worried I might get fat."

In April 2020, the Japanese government reported that gyms were a high potential source of infection, and many gyms decided to temporarily suspend activity (Ministry of Health, Labour and Welfare, 2020b; Steen, 2020). On the other hand, $18 \%$ of our participants talked about using home exercise products such as, "I bought a balance ball and am currently using it while doing simple exercises during breaks" or "I've decided to support local restaurants and use takeout. It's good for short exercise and I can get some fresh air for a while too." $12 \%$ of respondents expressed the desire to do exercise to lose or maintain weight, to be healthier, and to reduce fatigue.

\section{CONCLUSIONS}

This article uses qualitative research methods to examine the perceptions and feelings of remote working by employees in a Japanese corporation during the COVID-19 pandemic. On the whole the employees adapted to the shift in work environment and created mechanisms to overcome the lack of face-to-face interaction while sustaining the core of their corporate team culture. Nonetheless, other issues such as the lack of home space, an increase in childcare demands within work hours, and insufficient home office 
equipment created additional difficulties to work life. Friction at home between partners was created due to the fear of infringing upon the partner's work space and issues relating to the confidentiality of company data where partners worked for companies in direct competition with each other.

As a future direction, the researchers will focus on investigating whether employees' perceptions of remote work have changed, and determine how they feel about returning to traditional work-styles such as working from an office.

\section{ACKNOWLEDGEMENTS}

This study was conducted as part of a doctoral program at the Bucharest University of Economic Studies and at Babes Bolyai University.

\section{REFERENCES}

Aratani, L. (2020). How did Face Masks become a Political Issue in America? The Guardian. Retrieved July 17 2021. Available from: https://www.theguardian.com/world/2020/jun/29/face-masks-uspolitics-coronavirus

Borneo Post Online. (2019). Government to Study Rail System and Emulate Tokyo Station's Efficiency. Retrieved November 1 2021. Available from: https://www.theborneopost.com/2019/10/18/pmgovt-to-study-rail-system-and-emulate-tokyo-stations-efficiencyl

Burgess, A. \& Horii, M. (2012). Risk, Ritual and Health Responsibilisation: Japan's 'Safety Blanket' of Surgical Face Mask-Wearing. Sociology of Health and IIIness. 34(8): 1184-1198. Available from: https://onlinelibrary.wiley.com/doi/full/10.1111/j.1467-9566.2012.01466.x

Calimente, J. (2009). Rail Integrated Communities in Tokyo. The Journal of Transport and Land Use. 5 (1): 19-32. Available from: https://jtlu.org/index.php/itlu/article/view/280

Calisi, C. \& Stout, J. (2015). Stop Noise from Ruining Your Open Office. Harvard Business Review. Available from: https://hbr.org/2015/03/stop-noise-from-ruining-your-open-office

Detert, J.R. \& Burris, E.R. (2016). Can your Employees Really Speak Freely? Harvard Business Review. Available from: https://hbr.org/2016/01/can-your-employees-really-speak-freely

European Centre for Disease Prevention and Control. (2020). Use of Gloves in Healthcare and nonhealthcare Settings in the Context of the COVID-19 Pandemic. 2. July 2020. Available from: https://www.cnscbt.ro/index.php/1858-use-of-gloves-within-covid-19-02-07-2020/file

Inoue, A., Kawakami, N., Eguchi, H. \& Tsutsumi, A. (2018). Interaction effect of job insecurity and role ambiguity on psychological distress in Japanese employees: a cross-sectional study. International Archives of Occupational and Environmental Health. 91. Available from: https://link.springer.com/article/10.1007/s00420-018-1288-5

International Labour Organization (1986). Psychosocial Factors at Work: Recognition and Control. Report of the Joint ILO/WHO Committee on Occupational Health. Ninth Session. Geneva 18-24, September 1984. Occupational Safety and Health Series. No. 56. Available from: https://www.who.int/occupational health/publications/ILO WHO 1984 report of the joint com $\underline{\text { mittee.pdf }}$ 
International Labour Organization (2016). Workplace Stress, A Collective Challenge. International Labour Organization. Available from: https://www.ilo.org/wcmsp5/groups/public/---ed_protect/---protrav/--safework/documents/publication/wcms 466547.pdf

Iwasaki, A. \& Grubaugh, N.D. (2020). Why Does Japan Have So Few Cases of COVID-19? EMBO, Molecular Medicine. Available from: https://www.embopress.org/doi/pdf/10.15252/emmm.202012481

Kobayashi, M. (2015). Housing and Demographics: Experiences in Japan. Housing Finance International. Available from: https://www.jhf.go.jp/files/300304336.pdf

Lambe, M. (2019). Japanese Traditional Interior Design Elements. Working in Japan Today. Retrieved November 1 2021. Available from: https://workinjapan.today/life/japanese-traditional-interiordesign-elements/

Lithwick, D. (2020). Refusing to Wear a Mask is a Uniquely American Pathology. Slate. Available from: https://slate.com/news-and-politics/2020/05/masks-coronavirus-america.html

McDonald, B. \& Sylvester, K. (2014). Learning to get drunk: The importance of drinking in Japanese university sports clubs. International Review for the Sociology of Sport. 49(3/4): 331-345.

Ministry of Health, Labour and Welfare. (2020a). About Coronavirus Disease 2019 (COVID-19). MHLW. Available from: https://www.mhlw.go.jp/stf/seisakunitsuite/bunya/newpage 00032.html

Ministry of Health, Labour and Welfare. (2020b). Updates on COVID-19 in Japan. April 8th 2020. MHLW. Available from: https://www.mofa.go.jp/files/100045098.pdf

Morishima, M., Kishida, K., Uozumi, T. \& Kamijo, M. (2011). An Investigation of the Use of Hay Fever Masks for the Youth. Journal of Human Ergology. 40(1-2): 151-156. Available from: https://www.jstage.jst.go.jp/article/ihe/40/1 2/40 151/_pdf/-char/en

New York Times (Jun 2020). New York City Coronavirus Map and Case Count. Available from: https://www.nytimes.com/interactive/2020/nyregion/new-york-city-coronavirus-cases.html

Our World in Data. (May 2021). Statistics and Research. Coronavirus (COVID-19) Vaccinations. Retrieved May 10 2021. Available from: https://ourworldindata.org/covid-vaccinations

Pathmaranjan, R. (2003). Japanese Style of Team Working: The Unique Way and Characteristics. Journal of Management. 1(1): 34-40. Available from: http://www.seu.ac.lk/researchandpublications/fmc journal/jmiii/JOURNAL\%202003-4.pdf

Peron, J.P.S. \& Nakaya, H. (2020). Susceptibility of the Elderly to SARS-CoV-2 Infection: ACE-2 Overexpression, Shedding, and Antibody-depenednt Enhancement (ADE). CLINICS. Available from: https://www.scielo.br/pdf/clin/v75/1807-5932-clin-75-e1912.pdf

Prasad, R. (2020). Coronavirus: Why is there a US backlack to masks? BBC News. May 5. 2020. Available from: https://www.bbc.com/news/world-us-canada-52540015

Prime Minister of Japan and His Cabinet (2020). [COVID-19] Government Responses on the Coronavirus Disease 2019. July 1, 2020. Japan Government. Available from: http://japan.kantei.go.jp/ongoingtopics/ 00013.html

Reuters. (2021) COVID-19 Tracker. Available from: https://graphics.reuters.com/world-coronavirustracker-and-maps/countries-and-territories/japan/

Sakamoto, H. et al. (2018). Japan Health System Review. Health Systems in Transition. 8(1). Available from: https://apps.who.int/iris/bitstream/handle/10665/259941/9789290226260eng.pdf;jsessionid=B831492EF9A18F0C0428A7B686A9CC91? sequence $=1$ 
Shimomitsu, T. \& Haratani, T. (2000). Current Status of Occupational Stress and Health in Japan. The Journal of Tokyo Medical University. 58(3). Available from: https://ci.nii.ac.jp/naid/30024257069

Shteynbok, A. (2013). An Observation of the Superior-subordinate Relations in Japanese Companies in Japan and Sweden. Lund University. Available from: https://lup.lub.lu.se/luur/download?func=downloadFile\&recordOld=4076584\&fileOld=4076585

Sim, J. \& Waterfield, J. (2019). Focus Group Methodology: Some Ethical Challenges. Quality \& Quantity: International Journal of Methodology, 53: 3003-3022.

Statista. (2020a). Japan Confirmed Cases of Coronavirus by State of Health. Statista Research Department. Available from: https://www.statista.com/statistics/1096478/japan-confirmed-casesof-coronavirus-by-state-of-health/

Statista (2020b). Number of Cases of Coronavirus (COVID-19) in New York State as of June 2, 2020, by County. Statista Research Department. Available from: https://www.statista.com/statistics/1109360/coronavirus-covid19-cases-number-new-york-bycountyl

Statista (2020c). Share of People Suffering from Hay Fever and/or Allergies in Japan as of March 2019, by Type of Allergy. Statista Research Department. Available from: https://www.statista.com/statistics/831496/japan-types-of-allergy-hay-fever/

Statistics Bureau of Japan (2018). Housing and Land Survey. Portal Site of Official Statistics of Japan. Available from: https://www.stat.go.jp/english/data/jyutaku/results.html

Statistics Bureau (2019). Statistical Handbook of Japan. Ministry of Internal Affairs and Communications. Available from: https://www.stat.go.jp/english/data/handbook/pdf/2019all.pdf

Steen, E. (2020). These are the New Safety Regulations at Gyms and Fitness Centres in Tokyo. Timeout. Retrieved August 23, 2021. Available from: https://www.timeout.com/tokyo/news/these-are-thenew-safety-regulations-at-gyms-and-fitness-centres-in-tokyo-060320

Takehara, T. (2020). Recommendations from the Japanese Society of Hepatology June 8, 2020. Japan Society of Hepatology. Available from: https://www.jsh.or.jp/files/uploads/日本肝臓学会からの 提言_3.pdf

United States Census Bureau. (2021). Quarterly Residential Vacancies and Homeownership, Fourth Quarter. 2020. Available from: https://www.census.gov/housing/hvs/files/currenthvspress.pdf

World Health Organization. (2020). COVID-19 Strategy Update. 14 April 2020. Available from: https://www.who.int/docs/default-source/coronaviruse/covid-strategy-update-14april2020.pdf

Yamauchi, T., Takamatsu, M. and Imahori, S. (2017). Optimizing Train Stopping Patterns for Congestion Management. $17^{\text {th }}$ Workshop on Algorithmic Approaches for Transportation Modelling, Optimization and Systems (ATMOS 2017). Vol.59. Available from: https://drops.dagstuhl.de/opus/volltexte/oasics-complete/oasics-vol59-atmos2017complete.pdf\#page $=205$

Yu, W.H. and Kuo, J.C.L. (2019). Explaining the Effect of Parent-Child Coresidence on Marriage Formation: The Case of Japan. US National Library of Medicine. National Institutes of Health. Available from: $\underline{\text { https://www.ncbi.nIm.nih.gov/pmc/articles/PMC6385864/ }}$ 